\title{
Nefrogen systemisk fibrose ved bruk av MR-kontrastmiddel
}

\begin{abstract}
Sammendrag
Bakgrunn. Nefrogen systemisk fibrose er en ny og sannsynligvis iatrogen sykdom. Tilstanden ble første gang beskrevet i 2000 og ble i 2006 satt i sammenheng med bruk av MR-kontrastmidler med gadolinium hos pasienter med redusert nyrefunksjon.
\end{abstract}

Materiale og metode. Vi gir en oversikt over nefrogen systemisk fibrose basert på et ikke-systematisk litteratursøk og egen klinisk erfaring.

Resultater. Nefrogen systemisk fibrose er en alvorlig systemisk sykdom med aktivert inflammasjon og fibrosedanning, spesielt i hud, men også i flere andre vev, slik som skjelettmuskulatur, hjerte og oesophagus.

Fortolkning. Tilstanden er svært vanskelig å behandle. Påvisning av sykdommen har ført til endrede retningslinjer når det gjelder bruk av gadoliniumkontrastmidler hos pasienter med redusert nyrefunksjon.

\section{Rolf E.F. Christiansen}

rchr@helse-bergen.no

Medisinsk avdeling

Haukeland universitetssykehus

5021 Bergen

\author{
Lisbet Sviland \\ Avdeling for patologi \\ Gades Institutt \\ Haukeland universitetssykehus

\section{Ingegjerd Sekse} \\ Medisinsk avdeling \\ Haukeland universitetssykehus

\section{Einar Svarstad} \\ Medisinsk avdeling \\ Haukeland universitetssykehus \\ Universitetet i Bergen
}

Nefrogen systemisk fibrose er en sjelden sykdom, og det er ingen tidligere publiserte tilfeller i Norge. Vi har ved Haukeland universitetssykehus hatt en pasient som har fått denne diagnosen.

Forekomsten av kronisk nyresvikt er økende (1), og ledsagende komorbiditet, særlig kardiovaskulær sykdom, er vanlig hos pasienter som trenger dialyse eller transplantasjon (2). I forbindelse med utredninger av f.eks. karstrukturer vil det være behov for kontrastundersøkelser med jodholdige kontrastvæsker (CT-angiografi eller konvensjonell angiografi), og dette gir stor fare for akutt nyresvikt (kontrastnefropati) hos pasienter med nedsatt nyrefunksjon.

Ved introduksjon av MR og MR-kontrast (gadoliniumkontrastmidler) oppfattet man risikoen for kontrastnefropati hos pasienter med redusert nyrefunksjon som svært lav. Dette muliggjorde bruk av antatt mindre risikable og etter hvert lettere tilgjengelige radiologiske undersøkelser i denne pasientgruppen. Eksempler på aktuelle undersøkelser er MRangiografi av nyrekar ved mistanke om nyrearteriestenose og MR aorta i utredningen av nyresyke pasienter som forberedelse til nyretransplantasjon.

En mann i 30-årene ble nyretransplantert etter mangeårig IgA-nefritt. Han var arbeidsfør inntil han ble uføretrygdet sju år etter transplantasjonen. Pga. transplantatsvikt startet han peritoneal dialyse ett år etter transplantasjonen, med gradvis overgang til hemodialyse.

I forbindelse med utredning for ny nyretransplantasjon ble det gjennomført en MRangiografi av nyre- og bekkenarterier ti år etter han fikk nyretransplantat. I løpet av påfølgende måned beklaget han seg over klemfølelse i begge forføtter og gradvis mer uttalt nummenhet oppover leggene. Tre måneder etter kontrastundersøkelsen ble han hospitalisert pga. slapphet, hypotensjon og leddsmerter. Det ble påvist fortykket indurert hud rundt ankler. Han ble på nytt hospitalisert en måned senere pga. hypotensjon, stivhet i ankler/føtter og sviktende gangfunksjon.

Etter hvert fikk han nå mer uttalt hyperpigmentering omkring legger/ankler (fig 1) og indurert vev proksimalt for knærne og $i$ begge hender. Etter flere hudbiopsier uten representativt materiale, ble det ca. ett år etter MR-undersøkelsen tatt en dyp hudbiopsi fra underarm med påvisning av histologiske forandringer forenlig med nefrogen fibroserende dermopati (fig 2).

Mikroskopisk var der upåfallende epidermis, men betydelig økning av cellerikt bindevev i retikulære dermis og ned i septa. Det var spredte CD34-positive spolformede celler, mange CD68-positive celler og noen få små flerkjernede celler. Septa var tydelig fortykket med økt bindevevsdanning med kalsiumavleiringer både i bindevev og i karvegg.

Pasienten fikk på dette tidspunkt behandling med regelmessig hemodialyse. Det ble forsøkt en rekke tiltak mot hans nye sykdom. Det ble skiftet til hemodiafiltrasjon uten sikker effekt. Fotodynamisk terapi ble prøvd, men pga. smerter gjennomførte pasienten kun en sesjon. Han gjennomførte fire sesjoner med ekstrakorporal fotoforese, også dette uten sikker effekt.

Han ble etter hvert gradvis mer rullestolavhengig, hjelptrengende, til dels sykehjemspasient og hadde multiple sykehusinnleggelser. Allmenntilstanden ble stadig dårligere, og han døde i hjemmet 13 år etter transplantasjonen ble stilt, sannsynligvis av hjertestans.

\section{Hovedbudskap}

- Nefrogen systemisk fibrose er en fibroserende systemsykdom med høy morbiditet og mortalitet

- Bruk av gadoliniumholdige MR-kontrastmidler hos pasienter med alvorlig nyresvikt er den viktigste risikofaktoren

- Det er nylig utarbeidet mer restriktive retningslinjer for bruk av gadoliniumkontrastmidler ved nyresvikt 


\section{Materiale og metode}

Vi gir en oversikt over sykdommen basert på ikke-systematisk litteratursøk og egen klinisk erfaring.

\section{Bruk av MR-kontrast ved redusert nyrefunksjon}

I 2006 ble det publisert data som satte bruk av gadoliniumkontrastmidler hos pasienter med betydelig redusert nyrefunksjon i sammenheng med en ny, alvorlig systemisk sykdom kalt nefrogen systemisk fibrose (3). Dette førte til utarbeidingen av nye anbefalinger vedrørende bruk fra produsenter, Food and Drug Administration (FDA) i USA og etter hvert norske helsemyndigheter. Gadodiamid (Omniscan) er nå kontraindisert når glomerulær filtrasjonsrate (GFR) er under $30 \mathrm{ml} / \mathrm{min} / 1,73 \mathrm{~m}^{2}$, i tillegg til før og etter levertransplantasjon. Andre tilgjengelige gadoliniumkontrastmidler bør kun brukes etter nøye vurdering ved tilsvarende alvorlig nyresvikt (4).

Sykdommen ble første gang beskrevet i 2000 (5) hvor et tilfelle fra 1997 ble identifisert. Initialt oppfattet man at tilstanden var begrenset til hud og kalte den nefrogen fibroserende dermopati. Etter hvert som flere kasuistikker ble publisert, fremkom det klarere at det dreide seg om en systemsykdom som også kunne involvere annet vev som f.eks. lunger, oesophagus, skjelettmuskulatur, hjerte og dura mater $(6,7)$, og sykdommen benevnes nå nefrogen systemisk fibrose Det er hittil registrert 271 tilfeller (oktober 2007) av sykdommen på verdensbasis, og det er opprettet et internasjonalt forskningssenter ved Yale University, Connecticut, USA - International Center for Nephrogenic Fibrosing Dermopathy.

\section{Systemsykdom}

Nefrogen systemisk fibrose er en alvorlig fibroserende systemsykdom med betydelig økt sykelighet og dødelighet. Der er beskrevet en akutt fase (8), men de fleste tilfellene er klarere definert ved en kronisk fase som debuterer uker til måneder etter gadoliniumeksponering (ramme 1) (9).

Tilstanden affiserer typisk distale områder som føtter, hender og armer, og viser seg ofte som mer generalisert ødem etterfulgt av plakkliknende erytem og indurerte papler med en treaktig konsistens. Huden er ofte fortykket og hard, og forandringene kan til dels være uttalt smertefulle. Alopesi og hyperpigmentering av ekstremiteter kan følge, mens affeksjon av ansiktshuden forekommer svært sjelden. Systemisk affeksjon inkluderer tilstander som akutt pankreatitt, tromboser og hyppige infeksjoner. Sykdommen er ofte invalidiserende og kan føre til rullestolavhengighet/sengeleie forårsaket av blant annet redusert almenntilstand og leddkontrakturer.

Differensialdiagnostisk må man vurdere skleromyksødem, systemisk sklerose, morfea, eosinofil fasciitt, eosinofili-myalgi-syn- drom (EMS) og «Spanish toxic oil»-syndrom. De kliniske funn er her viktige. Diagnosen nefrogen systemisk fibrose baserer seg på et typisk klinisk bilde og histologisk undersøkelse av dyp hudbiopsi fra affisert område. Histologisk ses en proliferasjon av spolformede celler, med spredte monocyttære celler og små flerkjernede celler i dermis og subkutane septa. Immunhistokjemi har vist at de spolformede cellene er CD34-positive dendrittiske celler, mens de monocyttære og flerkjernede cellene er positive for CD68 (makrofager). I tillegg ses økt mengde kollagen, mucin og elastiske fibre. Histologisk kan det være vanskelig å skille nefrogen systemisk fibrose fra skleromyksødem, men i skleromyksødem ses som regel «sjøer» av mucin med plasmaceller og fragmenterte elastiske fibre som ikke er påvist hos pasienter med denne sykdommen. Biopsier fra systemisk sklerose eller morfea viser bunter av homogenisert kollagen og ingen proliferasjon av spolformede celler som er så karakteristisk for nefrogen systemisk fibrose.

\section{Diskusjon}

Nefrogen systemisk fibrose er en relativt ny sykdom hvor årsaksforhold, mekanismer for sykdomsutvikling og forekomst ennå ikke er avklart. Gadoliniumeksponering hos pasienter med redusert nyrefunksjon er identifisert som en vesentlig risikofaktor, noe som har ført til endrede retningslinjer for bruk av preparatet i denne pasientgruppen. I tillegg er det etter hvert påvist en del andre risikofaktorer for utviklingen av sykdommen (10), men den mest overbevisende etiologiske
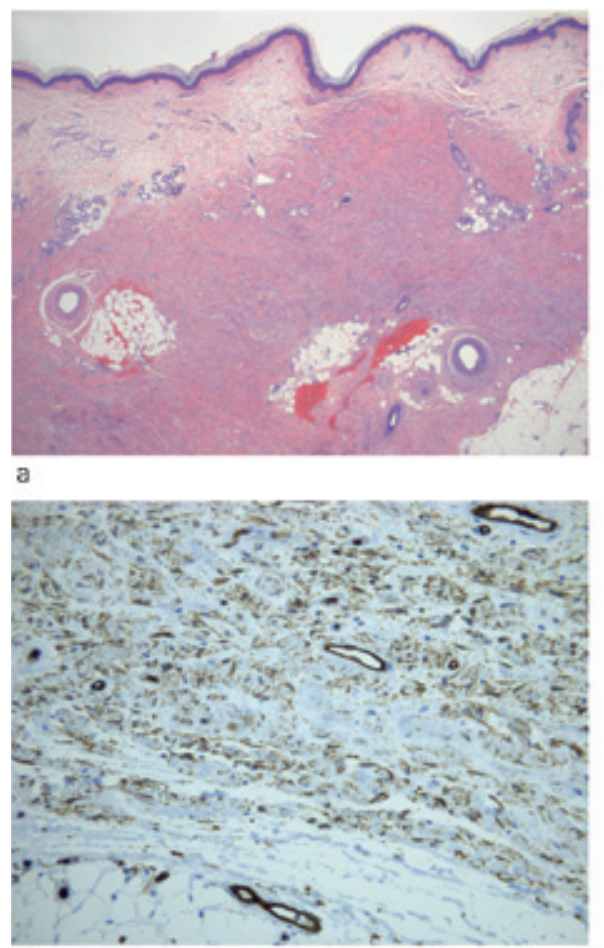

c

Figur 2 al Cellerik dermis og subcutis med økt bindevevsdanning. b) Utvidede septa med økt bindevev og spredte små flerkjernede celler. c) CD34-positive dendrittiske prosesser i dermis. d) CD68-positive celler i septa

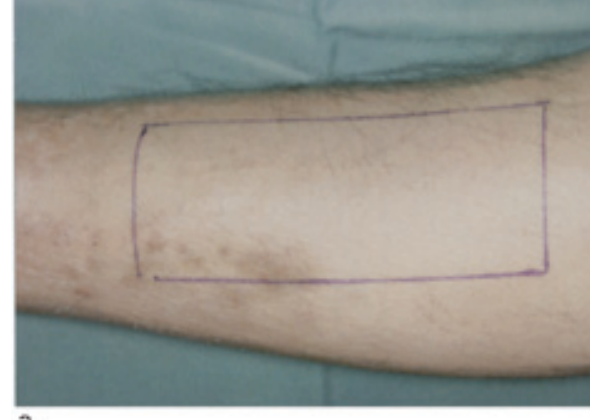

a

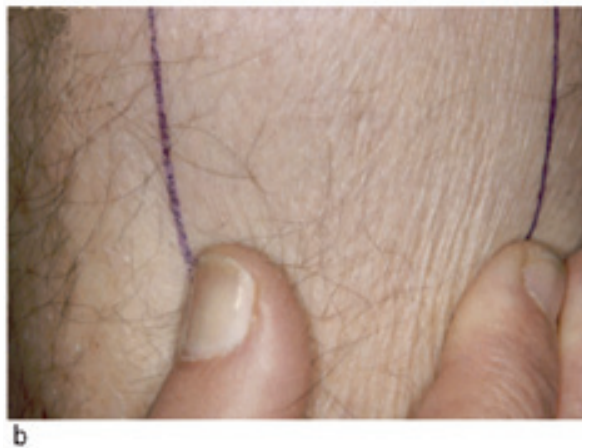

Figur 1 a) Bilde av indurert hudlesjon fra pasientens venstre legg. b) «Knipetest» som viser tap av elastisitet $i$ hud/underhud

faktor er fortsatt assosiasjonen til eksponering for gadolinium hos pasienter med nedsatt nyrefunksjon $(9,11,3)$. Assosiasjonen er styrket etter at gadolinium er påvist $i$ hudlesjonene (12).

De fleste tilfellene initialt beskrevet var knyttet til bruk av gadodiamid, men det er nå klart at det sannsynlig dreier seg om en klas-

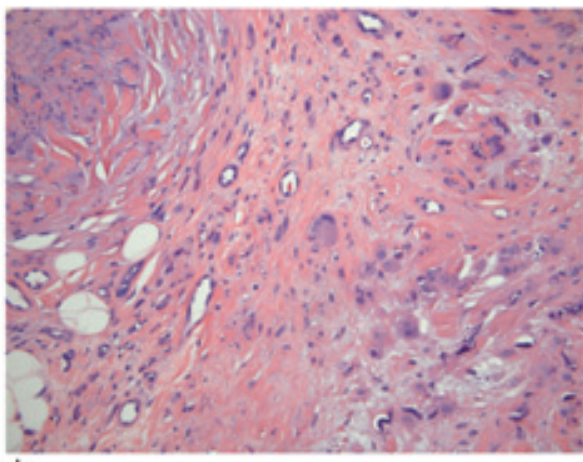

b

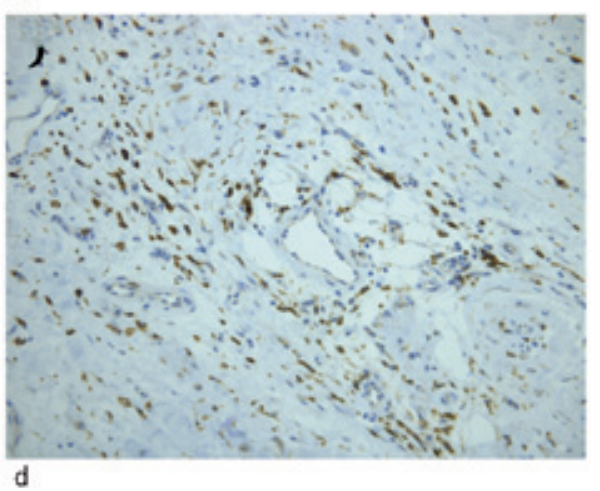




\section{Ramme 1}

Nefrogen systemisk fibrose ble første gang beskrevet i 2000 og senere i 2006 satt i sammenheng med bruk av gadoliniumkontrastmidler ved kronisk nyresvikt.

Sykdommen var først oppfattet å være begrenset til hud, men det er nå klart at det dreier seg om en sykdom med inflammasjon og $ø$ kt fibrosedanning i flere vev så som hud, lunger, oesophagus, hjerte og skjelettmuskulatur.

Fortsatt er mye uavklart vedrørende sykdommens patofysiologi, men aktivering av fibrocytter og transformerende vekstfaktor $\beta$ er involvert samtidig med en sannsynlig frigjøring og deponering av gadolinium $\mathrm{i}$ vev.

seeffekt av gadoliniumholdige kontrastvæsker, selv om det er sannsynlig at problemet er større eller mindre med enkelte preparater. Det gjelder de gadoliniumholdige MRkontramidlene på det norske markedet: gadopentetat (Magnevist), gadodiamid (Omniscan), gadoteridol (ProHance), gadotersyre (Dotarem), gadobutrol (Gadovist), dinatriumgadoksetinsyre (Primovist), gadofosveset (Vasovist) og gadobensyre (Multihance).

Risiko for utvikling av sykdommen er knyttet til redusert GFR-verdi og spesielt ved estimert GFR $<30 \mathrm{ml} / \mathrm{min}$, dvs. kronisk nyresykdom i stadium 4 og 5 (13). Utviklingen kan ses både ved akutt og kronisk nyresvikt og uavhengig av årsaksforhold for nyresvikten. I tillegg til gadoliniumeksponering synes ytterligere risikofaktorer, så som høydosert erytropoietinbehandling, forhøyet PTH og utbredt karsykdom å spille en rolle i utviklingen av sykdommen $(10,14)$.

Når det gjelder patofysiologi ved sykdomsutviklingen er fortsatt mye uavklart. Huden er fortykket som en følge av økt lokal kollagensyntese sekundært til fibrocyttaktivering og aktivering av transformerende vekstfaktor $\beta$ (transforming growth factor $\beta$, TGF- $\beta$ ) (4). Bildet karakteriseres av en vedvarende inflammasjonsliknende respons.

Idet sykdommen kun utvikles hos pasienter med redusert nyrefunksjon, er det nærliggende å forestille seg en toksisk effekt av endogent eller eksogent materiale. Gadolinium utskilles nesten utelukkende renalt, akkumuleres ved nyresvikt og assosiasjonen gadolinium-nyresvikt-nefrogen systemisk fibrose er godt dokumentert $(3,9)$. Gadoliniumkontrastmidler er vannløselige kontrastmidler som inneholder grunnmetallet gadolinium (Gd). Gadolinium er i utgangspunktet toksisk og holdes derfor naturlig i en reversibel kompleksstruktur (kelat) i løsningen. Man tenker seg at toksisk gadolinium frigjøres blant annet ved en transmetallisering med fritt jern $(4,14)$. Gadolinium deponeres i vev og setter i gang inflammasjon/fibrose. Ulik forekomst av nefrogen systemisk fibrose relatert til de forskjellige gadoliniumkontrasmidlene er sannsynlig relatert til preparatenes fysiokjemiske egenskaper og dermed ulik evne til å frigjøre gadolinium.

Det er i dag ingen klar enighet om hvilken behandling som er best for pasienter med nefrogen systemisk fibrose. Bedring av nyrefunksjonen (som f.eks. ved nyretransplantasjon) synes imidlertid å kunne stoppe utviklingen. Ellers er det forsøkt en rekke behandlingstiltak, men med kun få pasienter eller enkelttilfeller beskrevet. Man har forsøkt steroider, fotodynamisk terapi (15), fotoforese, plasmautskiftning og UV-behandling uten at man klart kan dokumentere gunstig effekt. I tillegg er pentoksyfyllin benyttet pga. antifibrotisk virkning og TNF- $\alpha$-blokade samt cellegiften cyklofosfamid. Men det er ikke dokumentasjon for at preparatene hjelper. Akutte avleiringer av gadolinium kan fjernes med dialyse. Dersom pasienter med betydelig redusert nyrefunksjon (kronisk nyresvikt stadium 3-5), likevel må gjennomgå gadoliniumbaserte kontrastundersøkelser, anbefales dialysebehandling umiddelbart etter eksponering og ny behandling etter 24 timer (16).

De norske retningslinjer er nå oppdatert vedrørende nyresvikt og bruk av gadoliniumkontrastmidler (17).

\section{Konklusjon}

Nefrogen systemisk fibrose er en nylig oppdaget alvorlig sykdom relatert til nyresvikt og sannsynlig bruk av gadoliniumkontrastmidler. Vi har beskrevet et tilfelle av sykdommen ved Haukeland universitetssykehus hos en pasient med alvorlig nyresvikt. Gadodiamid er kontraindisert ved GFR $<30 \mathrm{ml} /$ $\mathrm{min} / 1,73 \mathrm{~m}^{2}$, og andre tilgjengelige gadoliniumkontrastmidler bør kun brukes etter nøye vurdering ved tilsvarende alvorlig nyresvikt.

Pasientens pårørende har gitt samtykke til at artikkelen blir publisert.

Vi takker Lene Frøyen Sandvik og Dag Sollesnes Holsen ved Hudavdelingen, Haukeland universitetssykehus, for utlån av bilder av hudlesjon.

\section{Oppgitte interessekonflikter: Ingen}

\section{Litteratur}

1. Hallan SI, Coresh J, Astor BC. International comparison of the relationship of chronic kidney disease prevalence and ESRD risk. J Am Soc Nephrol 2006; 17: 2275-84.

2. Foley RN, Parfrey PS, Sarnak MJ. Epidemiology of cardiovascular disease in chronic renal disease. J Am Soc Nephrol 1998; 9: 16-23.

3. Grobner T. Gadolinium - a specific trigger for the development of nephrogenic fibrosing dermopathy and nephrogenic systemic fibrosis? Nephrol Dial Transplant 2006; 21: 1104-6.

4. Nortier JL, del Marmol V. Nephrogenic systemic fibrosis - the need for a multidisciplinary approach. Nephrol Dial Transplant 2007; 22: 3097-101.
5. Cowper SE, Robin HS, Steinberg SM et al. Scleromyxoedema-like cutaneous diseases in renal-dialysis patients. Lancet 2000; 356: 1000-1.

6. Ting WW, Stone MS, Madison KC et al. Nephrogenic fibrosing dermopathy with systemic involvement. Arch Dermatol 2003; 139: 903-6.

7. Cowper SE, Bucala R, Leboit PE. Nephrogenic fibrosing dermopathy/nephrogenic systemic fibrosis - setting the record straight. Semin Arthritis Rheum 2006; 35: 208-10.

8. Nephrogenic fibrosing dermopathy associated with exposure to gadolinium-containing contrast agents - St. Louis, Missouri, 2002-2006. MMWR Morb Mortal Wkly Rep 2007; 56: 137-41.

9. Marckmann P, Skov L, Rossen K et al. Nephrogenic systemic fibrosis: suspected causative role of gadodiamide used for contrast-enhanced magnetic resonance imaging. J Am Soc Nephrol 2006; 17: $2359-62$

10. Swaminathan S, Leung N. Nephrogenic fibrosing dermopathy and high-dose erythropoietin therapy. Ann Intern Med 2006; 145: 234-5.

11. Collidge TA, Thomson PC, Mark PB et al. Gadolinium-enhanced MR imaging and nephrogenic systemic fibrosis: retrospective study of a renal replacement therapy cohort. Radiology 2007; 245: 168-75.

12. High WA, Ayers RA, Cowper SE. Gadolinium is quantifiable within the tissue of patients with nephrogenic systemic fibrosis. J Am Acad Dermatol 2007; 56: 710-2.

13. Sadowski EA, Bennet LK, Chan MR et al. Nephrogenic systemic fibrosis: risk factors and incidence estimation. Radiology 2007; 243: 148-57.

14. Kanal E, Barkovich AJ, Bell C et al. ACR guidance document for safe MR practices: 2007. AJR Am J Roentgenol 2007; 188: 1447-74.

15. Schmook T, Budde K, Ulrich C et al. Successful treatment of nephrogenic fibrosing dermopathy in a kidney transplant recipient with photodynamic therapy. Nephrol Dial Transplant 2005; 20: 220-2.

16. Swaminathan S, Shah SV. New insights into nephrogenic systemic fibrosis. J Am Soc Nephrol 2007; 18: 2636-43.

17. Buajordet I, Madsen S. Alvorlige bivirkninger av Omniscan og Magnevist hos pasienter med nyresvikt. Oslo: Statens legemiddelverk, 2008.

Manuskriptet ble mottatt 9.2. 2008 og godkjent 30.5. 2008. Medisinsk redaktør Åslaug Helland. 